\title{
The Study on Factors That Influencing Banks' Non-Performing Loans in Malaysia
}

\author{
Yamunah Vaicondam, Sanil S Hishan, Tang Pik Shan
}

\begin{abstract}
The financial institution has played an important role to ensures macroeconomic stability in various economic sector. The effective and efficient performance in banking sector has contributed as an indicator of financial stability in any country. Non-performing advances have turned into the primary worry in research the factors that affecting the expansion of banks' non-performing advances in Malaysia. The main objective of the study is to study the factors that influence the bank's non-performing loans (credits) in Malaysia. The three main factors studied are inflation, unemployment and interest rate. The secondary data from the Bank Negara Malaysia and CEIC Data. All the banks in Malaysia was included for the study. The time period was for ten years between the year $2009-2018$. The results generated show consistency with the empirical studies and some contrary with the theories and finding of other researcher as well. The findings have shown the factors such as inflation, unemployment and interest rate has an influence in increasing the non-performing loans.
\end{abstract}

Keywords: Inflation, unemployment, interest rate, non-performing loans.

\section{INTRODUCTION}

The financial institution has played an important role to ensures macroeconomic stability in various economic sector. Banks are germane and act as a catalyst for economic development and growth of the countries through the financial services and market they provided. The effective and efficient performance in banking sector has contributed as an indicator of financial stability in any country [1]. A statement clearly explained that while well perform banking sector promotes economic growth, in contrast poorly functioning banking sector faced obstacle in aggravate poverty and economic progress. Therefore, economic growth of banking sector would not possible without a sound in any nation [2]. Studies have been conducted to demonstrate the factors that influence banks' non-performing loans in Malaysia. The past literatures similarly stressed on the inflation rate, interest rate and unemployment rate as factors that cause effect on non-performing loans [2] - [3]. From the past literature, it clearly stated that inflation rate, interest rate and unemployment factors have positively in relation with the non-performing loans. Other than these factors, according to Rinaldi and Sanchis (2006) [4], the study has investigated and found out that the disposable income is one of the reason

Revised Version Manuscript Received on April 19, 2019.

Yamunah Vaicondam, Faculty of Business, Accounting \&Management, Segi University, Malaysia.

Sanil S Hishan, Azman Hashim International Business School (AHIBS), Universiti Teknologi Malaysia, Malaysia.

Tang Pik Shan, Faculty of Business, Accounting \&Management, Segi University, Malaysia

adding to non-performing credits. If borrower has no fixed income or unemployed, the availability to repay debt will be affected. Therefore, the first issues of this report concentrate to examine unemployment factors that influencing banks' non-performing loans.

Furthermore, this study aimed to examine the unemployment factors that influencing banks' non-performing loans. According to the analysis conducted by Malaysia related government, Malaysia youth unemployment rate has hit a record of $10.8 \%$ in 2017. This issue was mainly contributed by the number of fresh grades students that are still unemployed, resulting in 204.000 numbers, $40.5 \%$ of the total unemployment. Unemployment among young people will result in long-term negative effect [5]- [6]. This will lead to bad loans and increase of default loans as the borrowers has insufficient income and capacity in repaying the debt. Thus, the second issue of this examination is to look at how unemployment factors has influence in increasing of banks' impaired loans in Malaysia.

As the review of Bank Negara Malaysia (BNM), non-performing credits proportion is required to build its OPR rate twice, results in $1.6 \%$ in May 2018. According to $\mathrm{S} \& \mathrm{P}$ financial institution, the rate of non-performing loans in Malaysian local bank will increase in between $1.8 \%$ to $2.0 \%$. The result showed that approximately corporate debt was $110 \%$; household debt in GDP ratio was $88.4 \%$. S\&P financial institution has discovered that jobless and financing cost could prompt increment of non-performing credits [7]. Consequently, the third issue of this study attempt to determine the main reasons that contribute banks' non-performing loans in household and business sector in Malaysia.

According to The Star Online in 2016, bad debt has become worse and trendy in most of the Asian banks includes Japanese, India and China. In the research, bad loans pile at the Asian banks has reached an amount of $\$ 171$ billion at the end of 2015. This result has been supported by the increase of $28 \%$ of non-performing loans in 2015 , twice growth of the amount of the year 2013 (The Star Online, 2016). If a country economy growth resulted in weak GDP, it will affect the ratio of bad loans, thus it might impact on increasing in non-performing loans. In other words, Gross domestic product will expedite impact banks' non-performing advances (non-performing credit) if the general monetary of a nation is stay low and frail. On that account, non-performing advances have turned into the primary worry in research the factors that 
affecting the expansion of banks' non-performing advances in Malaysia. The main purpose of this research is to examine the factors that influence banks' non-performing loans in Malaysia.

\section{LITERATURE REVIEW}

This study will focus on the factors that influencing banks' non-performing loans in Malaysia. There are many previous experiential studies which have investigated the consequences of macroeconomics variables and banks specific characteristic on the non-performing loans.

\section{A. Non-performing loans}

A credit that is in default and before long being in default is known as non-performing loans. In addition, Non-performing loan is defined as the loan is impaired, where the borrower's debt is outstanding for more than 3 months or 90 days. In other words, a loan that have not been paid or received any payments for more than 3 months is considered as non-performing loan [8]. In reference to the past studies, the analyst had discovered there is certain connection between large amounts of non-performing credits and low profitability [9]. Thus, the increment of non-performing loans has high potential in unfriendly impact on banks' overall performance, liquidity and profitability. There are illustrative components that reason the augmentation of non-performing advances in banks. There are a few exact examinations have been led on concentrating in one nation on the components that impacting banks' non-performing advances. Klein (2013) [10] and Rinaldi and Sanchis-Arellano (2006) [4] has examined on the macroeconomics factors of non-performing loans. These studies have been carried out in CESEE and European respectively. The results show that macroeconomics factors have associated with non-performing loans in terms of positive or negative connection. Different countries may face different economics difficulties and credit risk as the economics and financial instability.

In Malaysia, study have been introduced by Adebola et al (2011)[8] on the factors influencing non-performing loans. The results have shown that macroeconomics factors have influence in non-performing loans. High likelihood of number of credits default has expected in the expansion of non-performing advances. The changes of macroeconomics environment are contributing to the changes of the quality of banks on the debts and loans portfolio. This finding has been suggested by Festic et al (2011)[11]. This is because the greater environment will approach greater capability on the repayment of loans, hence lower the delinquency loans and default loans. The borrowers servicing ability and balance sheet income are affected by the external environment factors. The correlation of macroeconomics with non-performing loans is positive [12].

\section{B. Inflation rate and non-performing loans}

Inflation known as the overall rise in consumer price index, which represent a weighted average of prices for various goods and services. The change in consumer price index over a period of time is known as consumer price inflation [13]. According to Abid et al (2014)[14] and Klein (2013)[10] in Tunisia and CESEE respectively, inflation rate is one of the

explanatory variables of non-performing loans. In the discoveries, the expansion of swelling rate affects households' money related condition on the capacity of reimbursement advances. In this case, inflation has causes depreciation of the currency and economic climate. The high volatility index and lower growth will reduce the households' capacity in repayment of debts. As inflation increase, borrowings cost get more expensive, hence leads to worsening the quality of the loan portfolio. The goods and services tend to increase in prices and consumer faced difficult in income as not enough ability in servicing debts loan. This statement is proven by Kouser and Azeem (2012)[15]. The financial situation make household unable to commit obligation in loans payment. The economy slow will reflects on low GDP and inflation increase, hence, it directly connects to the accumulation of bad debt and impaired loans.

In reference to Radivojevic and Jovoni (2017)[16], the finding shows the impact of inflation rate in high interest rate has leads to declining economic conditions which will contribute to the borrowers' debt servicing capacities in loans. The statement is supported by Amuakwa-Mensah et al (2017)[17]. Besides, Kiayai (2003)[18] claims that poor monetary strategy will result in high expansion rate consequently contributing in ascents of non-performing advances. Notwithstanding, Jovovic (2014)[19] think about it is not in line and discovered that an irrelevant and positive relationship on the swelling rate and non-performing advances (credit default). This is because the inflation has cause depreciation on the money value but indirectly reduces the real value of loans. In this case, inflation rate and interest rate are evenly affecting in the non-performing loans either positively or negatively. A country that facing high inflation rate affect the borrowers' purchasing power as the prices of goods and services become more expensive. The borrowers faced insufficient cash flow to repay debts. There is an indication supported by Tagkalakis (2013)[20]. As the country is facing inflation, the borrowers may be suffering in depreciation in currency but benefits from the real value of debts.

The similar studies were presented by Alhassan et al (2014)[21] and Kjosevski and Petkovski (2017)[22], the outcomes discovered that inflation rate and non-performing advances has positive connection among one another. The inflation will reduce the capacity of the borrowers in repaying debts, hence it direct affected the rises in non-performing loans. In contrast, Rajha (2016)[2] has investigated and found out an adverse relationship between inflation rate and non-performing loans. The empirical study of Nkusu (2011)[12] has supported mentioned that inflation rate demonstrates positive or negative in affecting the accumulate in non-performing loans. This is on the grounds that increase of inflation helps as far as possible on credit installment by lessening the real value of the outstanding commitments. Therefore, the increase of inflation has contributed in affecting the ability of borrowers in repaying loans by weakens the financial condition of income. 
Moreover, there are several empirical studies that suggested that high inflation may results in negative effect on the non-performing loans. The study has been conducted by Chang (2002)[23] in Hong Kong. It mentioned that the adverse impact of inflation rate and impaired loans has leads to weaken in real value on repayment of debt. There is a supportive statement that matching the results which inflation rate has an undesirable outcome on the non-performing loans in Albanian banking system [24]. In fact, the banking system will result in reduces of non-performing loans when the inflation rate increase. Khemraj and Pasha (2009)[25] has proven on the inflation rate that has contribute to reduction of bad loans. The debts become easier and real value of debts decrease will contribute in lower delinquency. This is because the lenders adjust the interest rates in order to make some adjustment in real return, henceforth the borrowers have enough ability to pay for credits, interest cost can be bringing about impacting credit danger of nation banking framework.

\section{Unemployment rate and non-performing loans}

Unemployment refers to those are unemployed but willing to look for a job. The understanding on unemployment as simple as "people do not have a job". The unemployment rate can be figure up by the total of unemployed divided by the total of labor force [26]. Apart from these factors, Messai and Jouini (2013)[27] had been examine that unemployment rate have discovered a noteworthy and positive relationship along the non-performing credits. In fact, unemployed customers may not have the ability and commitment to repaying the loans, hence, this leads to the increasing of non-performing loans. This can be depicted as the expansion in joblessness rate will influence the obtaining intensity of the client and capacity in monetary commitment. Consequently, the unemployment rate adverse cash flows of household and increase burden in debts. The study has parallel findings with Makri et al (2014)[28] that have recorded a positive correlation between loan quality and unemployment, the ability of borrowers to pay loan instalment is affected due to the unemployment. It is notable that the unemployment rate has weakened borrowers' debt servicing capacity and make debtors more vulnerable to adverse in debt servicing problems.

Departing from the aforementioned studies, Radivojevic and Jovonic (2017) [16] has examined the connection between unemployment rate and (impaired loans) non-performing loans. The finding has supported with view that clearly illustrates that households' income uncertainty will weaken the borrowers' ability in repayment loan. Similar results were presented by Klein (2013) [10] study, it referenced that an expansion in joblessness will add to higher non-performing credits in banks, as unemployment rate has validated a strong connection between banking sector resilience and business cycle. At the point when joblessness is expanding, there is a normal increment on non-performing advances as the pay has considerable decrease [29]. Consequently, default debts may occur as loans payment might not be fully paid by the borrowers, hence causing of non-performing loans. The application on credit should be more restricted as to ensure the loans repayment does not affected by the unemployment rate. The information use to credit application is important as to identify on the individual or business firm whether they are servicing on defaulted debt or not.

There is an empirical study that has been examined on the unemployment factors that influencing the non-performing loans in banks. This statement has been proven in the Nordic banking system and Romania banking system, it shows that unemployment rate is sensitive and positive affected the non-performing loans [30]. The individual or business firm that are unemployed revealing that has not enough capability in repaying loans and thus leads to loans default [31]. The probability to default mostly because of an increase risk in the incidence of unemployed and income uncertainty of an individual. This is on the grounds that when financing cost of current credits increment, the purchaser may utilize current pay to serve the obligation [29]. Consequently, the abnormal state of non-performing advances happens as the salary is not sufficient to serve the obligation.

For this situation, the joblessness rate turns into a marker of non-performing credits as it is moderately touchy to one another either in individual or business firm perspective. The disposable income has positive and contributed to non-performing loans [4]. It is important that stability of financial system is closely related to money stability of individual and business firm as it directly affected the income condition.

Clearly from the above literature review, it is obvious that the previous studies had identifies some macroeconomics variables as determinants of non-performing loans. On the other hand, banks specific characteristics are used to determine banks' non-performing loans as well. Several factors are responsible for the non-performing loans in the countries. In such manner, the strand of literary works thinks about additional on the quantitative factors, which include inflation rate, interest rate and unemployment rate.

\section{Interest rate and non-performing loans}

Interest rate is the level of a measure of cash which is paid for its utilization for a timeframe. The bank implies the interest rate to the total unpaid portion of the loans or credit use. Interest rate can generate income as earning from the customers by borrowing the customer money. Apart from these factors, Messai and Jouini (2013)[27] study show there is a significant positive relationship in between interest rate and impaired loans. At the point when a bank rises genuine financing cost, it will straightforwardly prompt an expansion in non-performing credits. The floating rate affects the loan as changes in interest that will results in decreasing of the borrowers' ability in payment of loans. The discoveries are in accordance with Abid et al (2014)[14] and Rinaldi and Sanchis (2006)[4] that had concentrated on positive relationship between genuine loaning rates and non-performing advances in family unit obligations. As families' non-performing advances are sensitive to the adjustments in real lending rate. Most of the households' loans has varying rates that changes in the floating rates. 
When there is changes in loans rates, it will burden households' ability in repaying debts. Consequently, it will contribute to higher growth of non-performing loans. This can be explained as the banks adopt on the credit policies and lead to loans default [32].

Moreover, Adebola et al (2011) [8] has analyzed there is a huge connection between financing cost and non-performing credits. As it is normal, time of high loaning rate will cause non-performing advances rise which will influence the borrowers rate of default. In reference to the findings of empirical studies, Senawi et.al. (2014)[33] has demonstrated that premium has direct relationship in long run effect on non-performing credits; while premium does not impact non-performing advances in present moment in Malaysia business banks. his finding has been introduced by Bofondi and Ropele (2011)[34]. Default loans and bad loans has correlation relation with interest rate as the growth in interest rate weakens the financial condition and capacity of borrowers in the payment of debts. The borrowers may cause loans default and lead to asset and capital corrosion of banks.

In the investigation of Farhan et al (2012)[35], it reasoned that financing cost has very noteworthy connection on the non-performing credits in the Pakistani financial division. An expansion of financing cost will debilitate borrowers credit installment limit in this way brings about ascending of non-performing advances. The high correlation between interest rate and loans will enhances on debt default as it burdens the borrowers' financial income. The finding is supported by Nkusu (2011)[12]. In contrary, these findings are inconsistent with Rajha (2016)[2], as it appears there is a positive yet unimportant between financing cost and non-performing credits in Jordon banking part. Truth be told, borrower's capacity in paying would not influence by the financing cost, thusly do not effect on the non-performing credits. The finding is bolstered by Espinoza and Prasad (2010)[36]. As concluded, each country bank policy is different and may have different impact on the accumulate non-performing loans, either progressive or destructive depending on the economics of operation. A shaky financial framework can adjust into money related emergency as the high loan cost has trouble the budgetary salary of the purchaser, henceforth, adding to the expansion of non-performing credits and good dangers issue. In close, banks' loaning arrangement could have negative and vital impact on non-performing advances.

Based on this study, there are theory applied in explaining the non-performing loans. This section presents review of theories in light of the past examinations that have been directed. The theories include of information asymmetric theory, agency cost and credit default theory. This study is to examine the factors that influencing non-performing loans (non-performing credits) of banks in Malaysia. Based on the theory above, credit default theory is the most suit theory and maybe employ in examining non-performing loans. This is because concept of delinquency directly provides an understanding on the term of credit defaults which will influence in non-performing loans. The connection among delinquency and non-performing advances is certain where increment of misconduct (borrowers have inadequate income to pay the advance) will affect the ascent of non-performing credits.

When comes to Malaysia, there is a lack of observation and studies on the actual factors that influencing the banks' non-performing loans. Although, there are studies has been carried out by few researchers [37]- [38] - [8] in any case, there are a few calculates that as yet missing and unexplored on how it is really affecting the banks' non-performing advances in Malaysia. The factors such as unemployment rate and interest rate rarely been discussed in the previous studies that focus on Malaysia. Hence, this study is to focus on the inflation rate, unemployment rate and interest rate that influencing banks' non-performing loans in Malaysia.

\section{D.Research Framework}

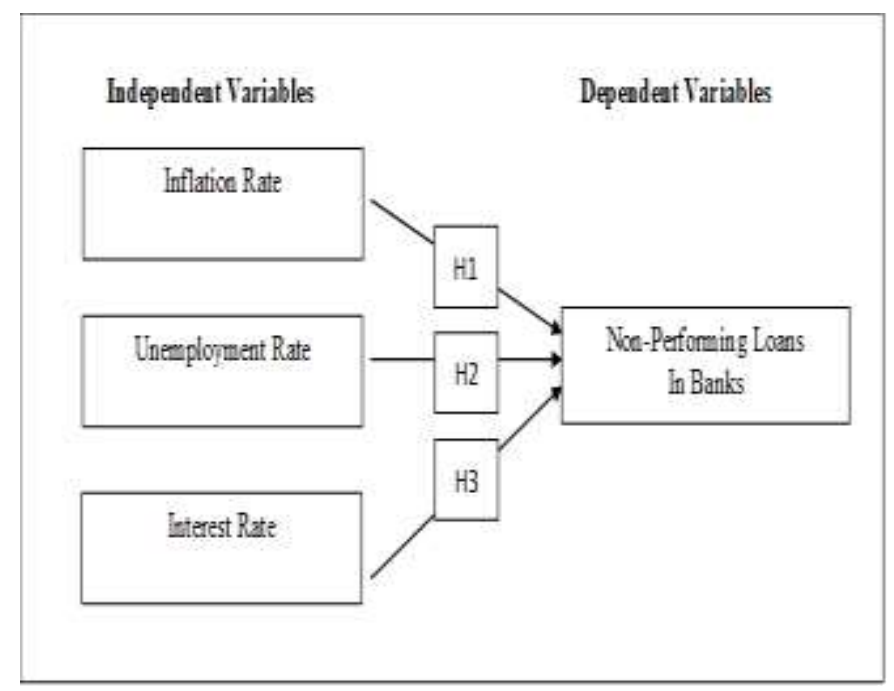

Figure 1 Factors that influencing banks' non-performing loans in Malaysia

Source: Bhattarai (2014)), Messai and Jouini (2013) and Farhan et al (2012)

Above Figure 1 shows the research studies on factors that have connection with the banks' non-performing loans in Malaysia. The connection between independent variables and dependent variables is shown in the figure.

\section{D.Research Hypothesis}

In this study, there is a positive and significant relationship on proposed framework and non-performing loans in banks. Based on the framework proposed, hypothesis have been formulated as following:

H1: There is a significant relationship between inflation rate and banks' non-performing loans in Malaysia.

$\mathrm{H} 2$ : There is a significant relationship between unemployment rate and banks' non-performing loans in Malaysia.

H3: There is a significant relationship between interest rate and banks' non-performing loans in Malaysia.

\section{RESEARCH METHODOLOGY}

The intention of this study is to examine the factors influencing banks' non-performing loans in Malaysia. This paper employs inflation rate, interest rate and unemployment 
rate as the variables of independent. The relationship in both variables will be carried out by using quantitative research method. Quantitative research is which the data concerned has been analyzed and readily interpreted. In secondary data analysis, it clearly stated that data collection process has obtain through other sources without directly involved. Therefore, secondary data is more preferable as the research method in this study. Data has been obtained using secondary data by extracting from Bank Negara Malaysia and Thomas Reuters. In this study, panel data is used for data collection. Panel data is employ to the independent and dependent variables as it cannot be observed and measured. This investigation is endeavor to decide the variables that impacting non-performing advances. The overall data analysis will be conducted for a period of time from the year 2009-2018. Future analysis is carried out by measure the GDP changes before and after the stable period accordingly. The year of 2009-2013 and 2014-2018 are interpreted and analyzed as the economic stage is different, GDP unstable and stable in the range of year respectively. The targeted population will be the loans default in Malaysian banking sector. The period of investigating non-performing loans will be between 2009 to 2018. In addition, it takes into consideration on the variables that influencing non-performing loans such as inflation rate, interest rate and unemployment rate.

Sampling is a fundamental operation for the auditing and statistical analysis of large data base. In reference to my study, probability sampling is employed to find out the actual factors that influencing banks non-performing loans in Malaysia. Census sampling technique is applying in investigate the relationship between independents and dependent variables. A census is gather of information about every member in the population of a nation. As this examination is center around the banks' non-performing loans in Malaysia, the data collection of census is suitable as it involves everyone in the data collected on the independent variables. (MyCensus Jabatan Perangkaan Malaysia, 2018). As this study is conducted in Malaysia, the whole population of the nations will take into account in interpreting the variables. The secondary data will be supported by few reliable sources includes Bank Negara Malaysia and CEIC Data. The sampling period will cover a total of 10 years, from 2009 to 2018. The data was collected on annual basis. This research method provided information on the entire population of a country (census) in relation to factors influencing (non-performing) loan default. The data collection on the independent variables are in the form of percentages based on Malaysia.

\section{$N P L=\beta o+\beta 1$ INF it $+\beta 2$ UNE it + $\beta 3$ INT it $+\in$ it}

Based on the literature review, it is clearly evidence which suggest that non-performing loans may be explained by macroeconomics factors. The model is a direct relapse work that connects the factors between independent and dependent variables. Hence the general regression equation is generated in is created in basic way as appear above [2] [39]-[40]-[41]. Where:

$$
\begin{aligned}
& \text { NPL }=\text { non-performing loans } \\
& \beta o=\text { constant coefficient } \\
& \beta 1=\text { coefficient of IV1 } \\
& \text { INF = inflation rate } \\
& \beta 3=\text { coefficient of IV2 } \\
& \text { UR = unemployment Rate } \\
& \beta 2=\text { coefficient of IV3 } \\
& \text { INT = interest Rate } \\
& E \quad=\text { error term }
\end{aligned}
$$

This study is to examine the factors influencing banks' non-performing loans in the country of Malaysia. Quantitative research instrument is used for data collection. Secondary data is collected by using reliable source. The sampling size is estimate in the period of 2009 to 2018 in examining the variables the effect on non-performing loans in Malaysia. Census is used as the research method as to collect population of the whole nation. Other than that, data analysis is well-defined. The correlation between independent and dependent variables is analysis based on the research topic. Consequently, research equation is generated.

\section{DATA ANALYSIS}

This part introduces the outcomes and discoveries of the examination on the factors that affecting banks' non-performing loans in Malaysia. Secondary data has been utilized for the investigation. The examination has been deciphered dependent on the information gathering from 2009 to 2018 on Malaysia commercial and Islamic banks. The data has obtained through reliable sources include Bank Negara, Economic Development Report and Department of Statistics Malaysia. In view of the underlying goal of this investigation, all data gathered is amassed to satisfy the requirement for all arrangement of testing has been carried out using the statistical software, SPSS. It extracted and interpret the data into table form.

\section{A. Descriptive Statistics}

Table 1 shows the descriptive statistics and the distribution of the variables has been concerned in this study: non-performing loans, inflation rate, unemployment rate and interest rate. The results indicate the factors of banks' non-performing loans in Malaysia in the time period of 10 years. The key figure of descriptive statistic consists of mean, standard deviation, minimum and maximum value are shown in the table.

Table 1 Descriptive Statistics

\section{Descriptive Statistics}

\begin{tabular}{|l|l|l|l|l|l|}
\hline & Mini & Max & Mean & Std. & Vari \\
mum & imu & & Devi & ance \\
& & $\mathrm{m}$ & & ation & \\
\hline
\end{tabular}


International Conference on Recents Advancements in Engineering and Technology (ICRAET-18) |15th and 16th March 2019|Siddhartha Institute of Technology \& Sciences, Telangana, India.

\begin{tabular}{|l|r|r|r|r|r|}
\hline $\begin{array}{l}\text { Inflation } \\
\text { Rate }\end{array}$ & 0.5 & 3.9 & 2.284 & \multicolumn{1}{l|}{1.013} & 1.02 \\
\hline $\begin{array}{l}\text { Unempl } \\
\text { oyment }\end{array}$ & 2.0 & 3.6 & 2.710 & 0.499 & 0.25 \\
Rate & & & & 9 & 0 \\
\hline $\begin{array}{l}\text { Interest } \\
\text { Rate }\end{array}$ & 5.51 & 7.01 & 6.528 & 0.409 & 0.16 \\
\hline $\begin{array}{l}\text { Non-Per } \\
\text { forming }\end{array}$ & 22.4 & 44.2 & 28.00 & 6.673 & 44.5 \\
Loans & & & 0 & 2 & 31 \\
\hline $\mathrm{N}=10$ & & & & \\
\hline
\end{tabular}

Table 1 above shows the overall data of 10 years in this study. The results indicate the overall average proportion of non-performing loans for Commercial and Islamic banking in Malaysia under the study was $28 \%$, annual average inflation rate was $2.28 \%$, annual unemployment rate was $2.71 \%$ and interest rate was $6.53 \%$. In addition, the result also shows the minimum and maximum of each independent variable in the period under thought. The standard deviation of ratio of non-performing loan, inflation rate, unemployment rate and interest rate were $6.67,1.01,0.50$ and 0.41 respectively.

\section{B. Correlation Analysis}

The above table shows the significant correlation of the finding. Table 2 shows the outcome of the correlation analysis for dependent and independent variables. The correlation value for the non-performing loans is 1 because the variable is correlated with itself. The outcome demonstrates that the proportion of non-performing loans of business and Islamic banks is emphatically corresponded with unemployment rate of p-value (0.855) significant at the 0.01 level. In addition, the non-performing credits has negative association with interest rate $(-0.908)$ and relationship is huge at the 0.01 dimension.

The results show that the non-performing loans of commercial and Islamic bank is negatively correlated with inflation rate $(-0.575)$ and no significant value. In the table 2 above, it also suggests that the correlation relationship between the independent variables. Unemployment rate has strong negative correlation with interest rate $(-0.644)$ and relevant at the 0.05 level.

Table 2 Pearson Correlations

\section{Pearson Correlations}

\begin{tabular}{|l|l|l|l|l|}
\hline & $\begin{array}{l}\text { Inflati } \\
\text { on }\end{array}$ & $\begin{array}{l}\text { Unemp } \\
\text { loymen } \\
\text { Rate }\end{array}$ & $\begin{array}{l}\text { Intere } \\
\text { st Rate }\end{array}$ & $\begin{array}{l}\text { Non-P } \\
\text { erform }\end{array}$ \\
\hline $\begin{array}{l}\text { Inflatio } \\
\text { n Rate }\end{array}$ & 1 & -0.573 & 0.583 & \multicolumn{1}{l|}{$\begin{array}{l}\text { ing } \\
\text { Loans }\end{array}$} \\
\hline $\begin{array}{l}\text { Unempl } \\
\text { oyment }\end{array}$ & -0.573 & 1 & -0.575 & $0.855^{*}$ \\
\hline
\end{tabular}

\begin{tabular}{|l|r|r|r|r|}
\hline Rate & & & & \\
\hline Interest & 0.583 & $-0.644^{*}$ & 1 & -0.908 \\
Rate & & & & $* *$ \\
\hline Non-Pe & -0.575 & $0.855^{*}$ & -0.90 & 1 \\
rformin & & $*$ & $8 * *$ & \\
g Loans & & & & \\
\hline $\mathrm{N}=10$ & & & & \\
\hline
\end{tabular}

*Correlation is significant at the 0.05 level ( 2 tailed).

** Correlation is significant at the 0.01 level ( 2 tailed).

\section{Simple Linear Regression}

Table 3 refer to the ANOVA table, significant value should be less than 0.05 to determine the model is fit to use for further analysis. The finding has demonstrated that the F-statistics is 39.832. The analysis of the significant value showed that the value is 0.000 where it falls below the suggested value of less than 0.05 . Therefore, the independent variables in the model jointly influence banks' non-performing loans in Malaysia. The model was in this manner thought about strong or then again fitted well to the genuine information of the variables.

Table 3 ANOVA ANOVA $^{\mathrm{a}}$

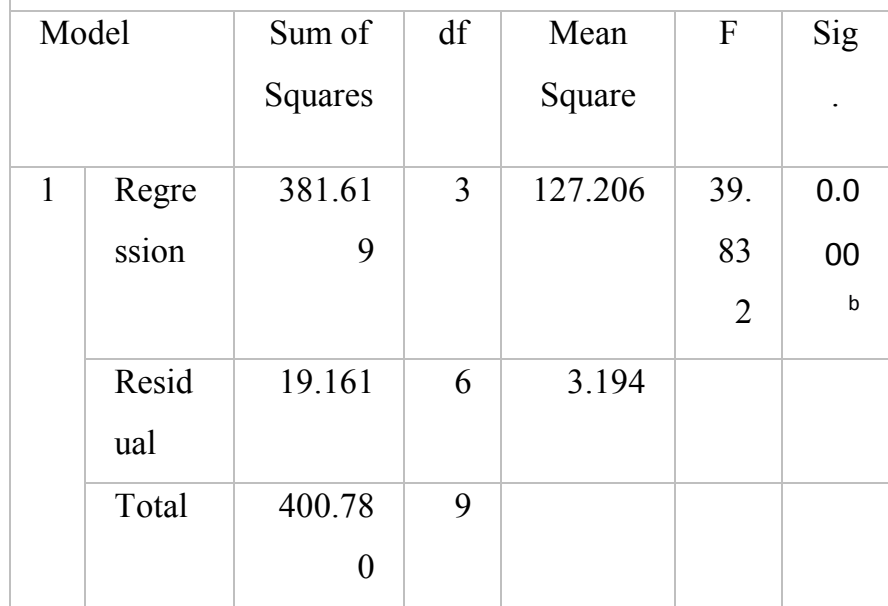

a. Dependent Variable: Non-Performing Loans

b. Predictors: (Constant), Interest Rate , Inflation Rate , Unemployment Rate

Overall of the results, this study has determined that the factors that influencing banks' non-performing loans. The regression analysis has been interpreted in the period of 10 years. By combine the data, the study has found out that the p-value (sig) is more favourable compare to the data that compute differently. The table 5, below has shown the results of coefficient in 10 years' time and the assumption is given as 
well. The table 4 shows the overall regression results for the period of 2009-2018. According to the regression established, taking all variables constant at zero, ratio of non-performing loans will be $77.19 \%$. At the level of significant and $95 \%$ level of confidence, this study has found out that the collinearity statistics of inflation rate had a tolerance factor of 0.593 , unemployment rate had tolerance factor of 0.526 and interest rate of 0.517 . These tolerance factors indicate that the independent variables have influences the non-performing loans in Malaysia. The examination found there are certain connection between inflation rate and non-performing credits, which shows that when inflation rate increase by 1 unit, non-performing loans increase by $7.7 \%$. The $\mathrm{p}$-value also results in 0.532 , which is not significant. The unemployment rate has positive coefficient on non-performing loans at the $10 \%$ significant level. This shows when joblessness rate increment by 1 unit, non-performing loans increase by $48.8 \%$. This is reliable with the connection investigation which recommends a positive relationship exists between the two factors. The results established that interest rate has adverse effect on non-performing loans at 5\% significant level. This can be explained as 1 unit increment in interest rate will prompt a decrease of $63.9 \%$ on the ratio of non-performing loans.

The factors that influencing the non-performing loans in commercial and Islamic banks were conducted using simple linear regressions. The results are revealed in Table 4.8 above. The study established the economic model as follows:

\section{$N P L$ it $=\beta o+\beta 1$ INF it $+\beta 2$ UNE it + $\beta 3$ INT it $+\in$ it}

Where,

NPL $=$ non-performing loans

$\beta o=$ constant coefficient

$\beta 1=$ coefficient of inflation rate

$\mathrm{INF}=$ inflation rate

$\beta 2=$ coefficient of interest rate

INT = interest Rate

$\beta 3=$ coefficient of unemployment rate

UR = unemployment Rate

E = error term

Simple Linear Regression Model based on 10 years data y it $=77.187+0.077$ (inflation rate) +0.488 (unemployment rate) -0.639 (interest rate) $(4.2)$

The above regression model is form by using the analysis data from table 4. It demonstrates that the independent variables have significant value that is below 0.05 . This can be concluded unemployment rate and interest rate are relating factor to the banks' non-performing loans in Malaysia.

\section{Hypothesis Results}

Table 4 Results of Hypothesis

\begin{tabular}{|l|l|c|c|}
\hline & Hypothesis & p-value & Result \\
\hline
\end{tabular}

\begin{tabular}{|l|l|l|l|}
\hline H1 & $\begin{array}{l}\text { There is an insignificant } \\
\text { relationship between } \\
\text { non-performing loans and } \\
\text { inflation rate. }\end{array}$ & 0.532 & Rejected \\
\hline H2 & $\begin{array}{l}\text { There is a significant } \\
\text { relationship between } \\
\text { non-performing loans and } \\
\text { unemployment rate. }\end{array}$ & Supported \\
\hline H3 & $\begin{array}{l}\text { There is a significant } \\
\text { relationship } \quad \text { between } \\
\text { non-performing loans and } \\
\text { interest rate. }\end{array}$ & Supported \\
\hline
\end{tabular}

The above table 4 shown the hypothesis results of the overall data (2009-2018). The results show that is an insignificant connection between non-performing loans and inflation rate. On the unemployment rate factors, there is a significant connection with the non-performing credits. The table also suggested that there is significant relationship between the non-performing loans and interest rate

Table 5 Regression Results for overall year 2009-2018 Coefficients $^{\text {a }}$

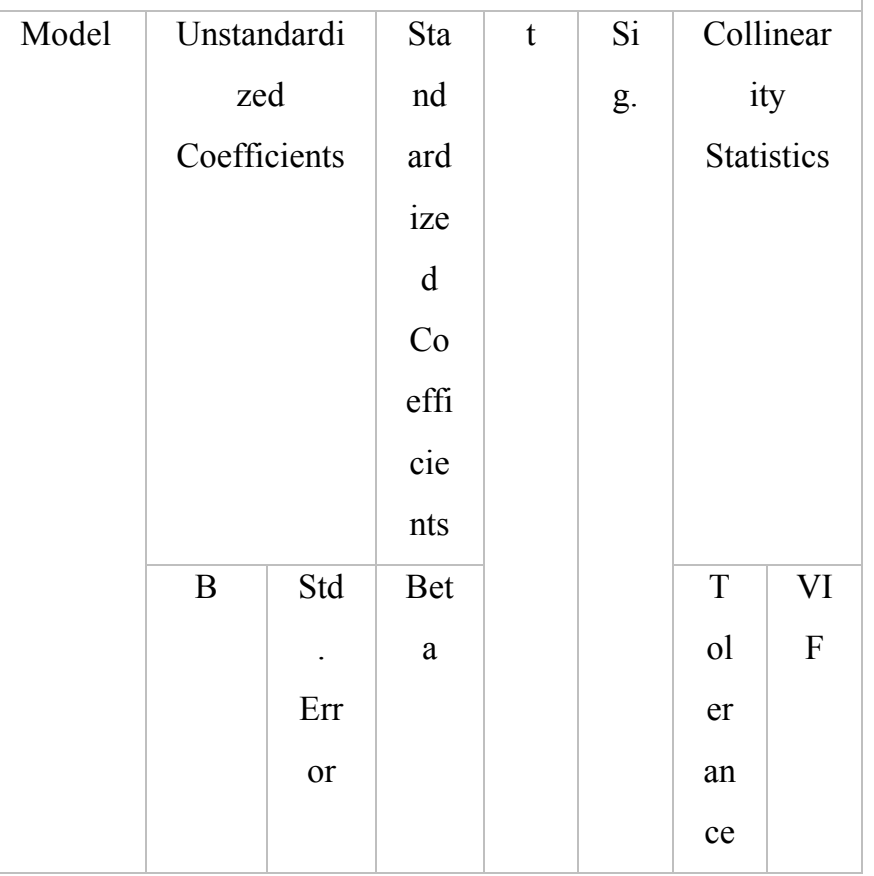




\begin{tabular}{|c|c|c|c|c|c|c|c|}
\hline $\begin{array}{ll}1 & (\text { Co } \\
\text { nst } \\
\text { ant } \\
\text { ) }\end{array}$ & $\begin{array}{r}77.1 \\
87\end{array}$ & $\begin{array}{r}15 . \\
54 \\
7\end{array}$ & & $\begin{array}{r}4 . \\
96 \\
5\end{array}$ & 00 & & \\
\hline $\begin{array}{l}\text { Infl } \\
\text { atio } \\
\mathrm{n} \\
\text { Rat } \\
\text { e }\end{array}$ & $\begin{array}{r}0.50 \\
6\end{array}$ & $\begin{array}{r}0.7 \\
63\end{array}$ & $\begin{array}{r}0.0 \\
77\end{array}$ & $\begin{array}{r}0 . \\
66 \\
3\end{array}$ & 53 & $\begin{array}{r}0 . \\
59 \\
3\end{array}$ & 68 \\
\hline $\begin{array}{l}\text { Un } \\
\text { em } \\
\text { plo } \\
\text { ym } \\
\text { ent } \\
\text { Rat } \\
\text { e }\end{array}$ & $\begin{array}{r}6.51 \\
0\end{array}$ & $\begin{array}{l}1.6 \\
43\end{array}$ & $\begin{array}{r}0.4 \\
88\end{array}$ & $\begin{array}{r}3 . \\
96 \\
2\end{array}$ & 00 & $\begin{array}{c}0 . \\
52 \\
6\end{array}$ & 90 \\
\hline $\begin{array}{l}\text { Int } \\
\text { ere } \\
\text { st } \\
\text { Rat } \\
\text { e }\end{array}$ & $\begin{array}{l}-10 . \\
413\end{array}$ & $\begin{array}{l}2.0 \\
24\end{array}$ & $\begin{array}{r}-0 . \\
63 \\
9\end{array}$ & $\begin{array}{l}-5 \\
.1 \\
45\end{array}$ & 00 & $\begin{array}{r}0 . \\
51 \\
7\end{array}$ & 93 \\
\hline
\end{tabular}

a. Dependent Variable: Non-Performing Loans

\section{DISCUSSION AND CONCLUSION}

In this study, non-performing loans has drawn the attention of the public, as it brings negative impact to the economy. So as to see decisively about the reason for non-performing advances, this exploration is to see if the free factors are altogether assuming significant job in influencing non-performing credits in Malaysia. Based on the study findings, this examination has effectively demonstrated that free factors have critical association with non-performing advances and the normal outcomes for every autonomous variable are predictable to the experimental investigations that have been talked about in the writing survey.

In the study, the researcher would like to advice few of the recommendations for future studies. First and foremost, this study has only conducted based in Malaysia due to the limited of time. The data collected is accumulated within a country only and results in less flexibility in the analysis. The future researcher may consider choosing more than one country in this data analysis in order to analyse the other factors in other nations. This is to have better analysis in comparing the countries whether the economy is in healthy condition. Furthermore, the secondary data that have been collected is based on annually due to the time constraints. Data were used to run the analysis and make assumption on this study is based on the annual basis. Perhaps, if the monthly data or quarterly data is collected, the analysis will be more accurate. This is because each quarter or weekly has different number of data, hence will have different outcomes. Researcher in future studies should consider bigger sample size and finds more journals in supporting the findings. With increasingly demonstrated and exact survey, results will be additional persuading and firm.

Other than this, the future studies are recommended to concern on the internal factor rather than external factor. The internal factors include of credit management, lender/borrower behaviour, policies and loan management. It also suggests than the internal factor will also affect the banks' non-performing credits (loans) in Malaysia. The difference between the factors in this study and internal factors, which is the methodologies used. The researcher may require to use different methodologies under the qualitative factors. As a conclude, researchers may be more concern on the other factors that ought to be considered in the examination.

The investigation has started with an idea to gather the information on yearly premise of 30 years. Sadly, there are many missing information exist in that period. This has affected the data available on the period of study. Finally, the investigation has been led on the time of 2009-2018 on yearly premise to decide the huge contrasts between non-performing advances and different factors. Besides, there is only few researchers have conducted research on non-performing loans in Malaysia. Consequently, it is hard to get the data and diaries dependent on Malaysia examines. The most efficient way is to review journal based on the European countries and it has found out that is unequivocally enough to help this exploration venture particularly in literature review. Other than this, this study has been limited on the population. This study conducted determine the factors of banks' non-performing loans but other private or public financial institution has not taken into account. This study has lack of consideration on the sector view in order to give an expansive based examination.

Overall the objective this paper is to decide the elements that influence banks' non-performing loans in Malaysia. In this investigation, the goal has been accomplished by demonstrating how the independent variables (inflation rate, unemployment rate and interest rate) influence the banks' non-performing loans in Malaysia. SPSS tool used to compute the secondary data obtained from the official website and Bank Negara Malaysia. The data obtained refers to the non-performing loans for conventional and Islamic banks from the year 2009 to 2018 . Normality test and other test are used to check on the reliability on the data. The date has been interpreted and analysis has been done. The results generated show consistency with the empirical studies and some contrary with the theories and finding of other researcher as well. Although there is limitation on the studies, however the future researcher may seek for improvement by using this study as a guideline based on the suggestion given. 


\section{REFERENCES}

1. Kolapo TF, Ayeni RK, Oke MO. CREDIT RISK AND COMMERCIAL BANKS'PERFORMANCE IN NIGERIA: A PANEL MODEL APPROACH. Australian journal of business and management research. 2012 May 1;2(2):31.

2. Rajha KS. Determinants of non-performing loans: Evidence from the Jordanian banking sector. Journal of Finance and Bank Management. 2016 Jun;4(1):125-36.

3. Pakistan PC. Abdullah, S.(1993), Flames of the Chinar, New Delhi: Viking. Acemoglu, D., Johnson, S. and Robinson, JA (2001), "The Colonial Origins of Comparative Development: An Empirical Investigation", American Economic Review, 91, pp. 1369-1401. Afzal, MR (1976), Political Parties in Pakistan: 1947-1958, Islamabad: National. Democratic Transition and Security in Pakistan. 2015 Oct 23:259.

4. Rinaldi L, Sanchis-Arellano A. Household debt sustainability: what explains household non-performing loans? An empirical analysis. 2016

5. Halim, F. The Edge Financial Daily. Youth Unemployment Rate Still High. Retrieved from http://www.theedgemarkets.com/article/youth-unemployment-ra te-still-high. 2018 May 4.

6. Dass, A., The Star Online. Young and Jobless in Malaysia. Retrieved

from https://www.thestar.com.my/business/business-news/2018/08/0 6/young-and-jobless-in-malaysia/ 2018 August 6.

7. Hou Y, Dickinson D. The non-performing loans: some bank-level evidences. In4th International Conference on Applied Financial Economics, Samos Island, Greece 2007 Aug.

8. Adebola SS, Yusoff W, Dahalan J. An ARDL approach to the determinants of nonperforming loans in Islamic banking system in Malaysia. Kuwait Chapter of Arabian Journal of Business and Management Review. 2011 Oct;33(830):1-1.

9. Ombaba KB. Assessing the Factors Contributing to Non-Performance Loans in Kenyan Banks.2013

10. Klein N. Non-performing loans in CESEE: Determinants and impact on macroeconomic performance. International Monetary Fund; 2013 Mar 20.

11. Festić M, Kavkler A, Repina S. The macroeconomic sources of systemic risk in the banking sectors of five new EU member states. Journal of Banking \& Finance. 2011 Feb 1;35(2):310-22.

12. Nkusu MM. Nonperforming loans and macrofinancial vulnerabilities in advanced economies. International Monetary Fund; 2011 Jul 1.

13. Labonte M, Makinen GE. Inflation: causes, costs, and current status. Congressional Research Service, Library of Congress.

14. Abid L, Ouertani MN, Zouari-Ghorbel S. Macroeconomic and bank-specific determinants of household's non-performing loans in Tunisia: A dynamic panel data. Procedia Economics and Finance. 2014 Jan 1;13:58-68.

15. Kouser R, Bano T, Azeem M, Ul Hassan M. Inter-relationship between profitability, growth and size: A case of non-financial companies from Pakistan. Pakistan Journal of Commerce and Social Sciences (PJCSS). 2012;6(2):405-19.

16. Radivojevic N, Jovovic J. Examining of determinants of non-performing loans. Prague Economic Papers. 2017 Jun 1;26(3):300-16

17. Amuakwa-Mensah F, Marbuah G, Ani-Asamoah Marbuah D. Re-examining the determinants of non-performing loans in Ghana's banking industry: Role of the 2007-2009 financial crisis. Journal of African Business. 2017 Jul 3;18(3):357-79.

18. Kiyai TK. Bad debts restructuring techniques and non-performing loans of commercial banks in Kenya (Doctoral dissertation, University of Nairobi).2003.

19. Jovovic J. Determinants of Non-Performing Loans: Econometric Evidence Based on 25 Countries (Doctoral dissertation, Master thesis, City University London).2014.

20. Tagkalakis AO. The unemployment effects of fiscal policy: recent evidence from Greece. IZA Journal of European Labor Studies. 2013 Dec 1;2(1):11.

21. Alhassan AL, Biekpe N. Insurance market development and economic growth: Exploring causality in 8 selected African countries. International Journal of Social Economics. 2016 Mar 7;43(3):321-39.

22. Kjosevski J, Petkovski M. Non-performing loans in Baltic States: determinants and macroeconomic effects. Baltic Journal of Economics. 2017 Jan 2;17(1):25-44.
23. Shu C. The impact of macroeconomic environment on the asset quality of Hong Kong's banking sector. Hong Kong Monetary Authority Research Memorandums. 2002 Dec;2002:1-26.

24. Shingjergji A. The Impact of Macroeconomic Variables on the Non Performing Loans in the Albanian Banking System During 2005-2012. Academic Journal of Interdisciplinary Studies. 2013 Sep 29;2(9):335

25. Khemraj T, Pasha S. The determinants of non-performing loans: an econometric case study of Guyana.2009.

26. Hudson VM. Foreign policy analysis: classic and contemporary theory. Rowman \& Littlefield; 2013 Dec 5.

27. Messai AS, Jouini F. Micro and macro determinants of non-performing loans. International journal of economics and financial issues. 2013 Sep 19;3(4):852-60.

28. Makri V, Tsagkanos A, Bellas A. Determinants of non-performing loans: The case of Eurozone. Panoeconomicus. 2014 Oct 10;61(2):193-206.

29. Berge TO, Boye KG. An analysis of banks' problem loans.2007.

30. Joseph MT, Edson G, Manuere F, Clifford M, Michael K. Non performing loans in commercial banks: a case of CBZ Bank Limited in Zimbabwe. Interdisciplinary Journal of Contemporary Research in Business. 2012 Nov;4(7):467-88.

31. Vogiazas SD, Nikolaidou E. Credit risk determinants in the Bulgarian banking system and the Greek twin crises. InMIBES International conference 2011 (pp. 177-189).

32. Ricardo-Gonzalez RR, Nguyen M, Gokden N, Sangoi AR, Presti JC, McKenney JK. Plasmacytoid carcinoma of the bladder: a urothelial carcinoma variant with a predilection for intraperitoneal spread. The Journal of urology. 2012 Mar;187(3):852-5.

33. Senawi AR, Isa MP. Gold price as a determinant of non-performing loans: An analysis of Malaysia. Global Business and Management Research. 2014 Oct 1;6(4):300.

34. Bofondi M, Ropele T. Macroeconomic determinants of bad loans: evidence from Italian banks. Bank of Italy Occasional Paper. 2011 Mar 22(89)

35. Farhan A, Obaid SN, Azlan H. Corporate governance effect on firms' performance-evidence from the UAE. Journal of Economic and Administrative Sciences. 2017 May 15;33(1):66-80.

36. Espinoza RA, Prasad A. Nonperforming loans in the GCC banking system and their macroeconomic effects. International Monetary Fund; 2010 Oct 1.

37. Ismail A, Hanif R, Choudhary S, Nisar A. Income-diversification in banking sector of Pakistan: a'Blessing'or'Curse'?. The Journal of Commerce. 2015;7(1):11.

38. Karim MZ, Chan SG, Hassan S. Bank efficiency and non-performing loans: Evidence from Malaysia and Singapore. Prague Economic Papers. 2010 Feb;2(1):118-32.

39. Zia H, Harris N, Merrett G, Rivers M. Predicting discharge using a low complexity machine learning model. Computers and Electronics in Agriculture. 2015 Oct 1;118:350-60.

40. Hishan SS, Khan A, Ahmad J, Hassan ZB, Zaman K, Qureshi MI Access to clean technologies, energy, finance, and food: environmental sustainability agenda and its implications on Sub-Saharan African countries. Environmental Science and Pollution Research. 2019 Jun 1;26(16):16503-18.

41. Batool R, Sharif A, Islam T, Zaman K, Shoukry AM, Sharkawy MA, Gani S, Aamir A, Hishan SS. Green is clean: the role of ICT in resource management. Environmental Science and Pollution Research. 2019 Jun 29:1-8. 